\title{
ВОДОПОЛЬЗОВАНИЕ
}

\section{ANALYSIS OF DESIGNS OF COMPACT WASTEWATER TREATMENT PLANTS}

\author{
Ambrosova G. T., Kruglikova A. V., Kolodeznikova A. P., Semenova A. P.
}

\section{АНАЛИЗ ТЕХНИЧЕСКИХ РЕШЕНИЙ КОМПАКТНЫХ УСТАНОВОК ДЛЯ ОЧИСТКИ СТОЧНОЙ ЖИДКОСТИ}

\author{
Амбросова Г. Т., Кругликова А. В., Колодезникова А. П., Семенова А. П.
}

\begin{abstract}
Introduction. In this paper, we consider the operation principle, features, advantages, and disadvantages of compact domestic wastewater treatment plants designed by domestic manufacturers. The compact plants used until 2000 were designed to reduce such two indicators in the waste liquid as BOD and suspended solids. Since 2000, modern compact plants capable of reducing four indicators (BOD, suspended solids, nitrogen, and phosphorus) have been developed and installed in Russia. Methods. Biological methods of removing organic substances and nitrogen from the waste liquid are used at modern compact plants. Phosphorus is removed by using both biological and physical-and-chemical methods. The main issue in the operation of compact domestic wastewater treatment plants is the extremely nonuniform flow of wastewater; the coefficient of hourly nonuniformity can be 3.5 or higher. Another serious issue is the reduction in the waste liquid temperature in the cold period to critical values that hinder the biochemical oxidation of organic substances in aeration tanks. In permafrost areas (Yakutia), the influence of this factor can be observed even in the warm period. Results. Based on theoretical research and many years of experience in commissioning, we identified the consequences of design flaws and violations during operation for the stability and performance efficiency of compact plants of various modifications. Conclusion. The performed study made it possible to develop and recommend the optimal option for wastewater treatment, which allowed us to ensure that the indicators were brought to the maximum permissible concentrations of pollutants (suspended solids $-2-3 \mathrm{mg} / \mathrm{l}, \mathrm{BOD}_{\text {ult }}-3-5 \mathrm{mg} / \mathrm{l}$, ammonium nitrogen $-0.4 \mathrm{mg} / \mathrm{l}$, nitrate nitrogen $-9 \mathrm{mg} / \mathrm{l}$, phosphorus $-0.2 \mathrm{mg} / \mathrm{l}$ ), established for discharge into fishing reservoirs.
\end{abstract}

Keywords: compact plants, wastewater treatment, nitrogen and phosphorus removal, waste liquid temperature, modern technology.

\footnotetext{
Аннотация

Введение. В настоящей работе рассмотрены принцип действия, особенности, достоинства и недостатки компактных установок, предназначенных для очистки бытовых стоков, предлагаемых отечественными производителями. Применяемые до 2000 года компактные установки рассчитывались на снижение в сточной жидкости двух показателей: БПК и взвешенных веществ. С 2000 года и по настоящее время в Российской Федерации разрабатывают и монтируют современные компактные установки, способные снижать четыре показателя: БПК, взвешенные вещества, азот и фосфор. Методы. В современных компактных установках использованы биологические методы удаления из сточной жидкости органических веществ и азота. Удаление фосфора осуществляется как биологическим, так и физико-химическим методами. Основной проблемой при эксплуатации компактных установок, предназначенных для очистки бытовых стоков, является крайне неравномерное их поступление; коэффициент часовой неравномерности может составлять 3,5 и более. Серьёзной проблемой при эксплуатации компактных установок является снижение температуры сточной жидкости в холодный период года до критических значений, препятствующих протеканию процессов биохимического окисления органических веществ в аэротенках. В районах с вечной мерзлотой (Якутия) влияние этого фактора заметно даже в теплый период года. Результаты. Авторами настоящей работы на основании теоретических исследований и многолетнего опыта наладочных работ удалось выявить последствия проектных недоработок и нарушений в процессе эксплуатации для стабильности и эффективности работы компактных установок разных модификаций. Заключение. Выполненная работа позволила разработать и рекомендовать оптимальный вариант очистки сточной жидкости, позволяющий обеспечить доведение показателей до предельно допустимых концентраций загрязнений (взвешенные вещества 2-3 мг/л, БПК сброса в рыбохозяйственные водоёмы.

Ключевые слова: компактная установка, очистка стоков, удаление азота и фосфора, температура сточной жидкости, современная технология.
} 


\section{Introduction}

The purpose of this paper is to critically analyze the existing designs of compact plants (CP) by domestic manufacturers in order to identify and eliminate flaws in design and wastewater and sludge treatment technology so as to prevent their replication during the design of new facilities and select less expensive options for the enhancement of the operation of the existing CPs. At present, in the Republic of Sakha (Yakutia), the issue of improving the sanitary condition of nine uluses (villages) is being resolved through the construction of CPs that will receive wastewater delivered by sewage trucks from cesspools and ensure its treatment. In this severe climatic region with a short summer and permafrost, wastewater discharge to land creates serious problems, primarily related to air basin pollution by malodorous and carcinogenic gases: hydrogen sulfide, ammonia, indole, and mercaptans.

The present work was started with an indepth analysis of literature data on wastewater treatment carried out in CPs $[3,6,7,10]$. The review showed that CPs capable of removing soluble and insoluble substances of organic and mineral origin, as well as biogenic elements other than sulfur, have been developed and used since about 2000. The nitrogen removal technology is based on nitrification and denitrification methods; to reduce phosphorus to standard values, the biological and the chemical method are used in combination $[5,11,12,15]$. The biological method implies phosphorus removal at the stage of biological wastewater treatment, which results in phosphorus spent on the synthesis of biomass.

Small wastewater treatment complexes are characterized by extremely nonuniform flow of wastewater, both in terms of water and in terms of pollution. In order to ensure a constant and uniform supply of wastewater for treatment, equalization tanks are included in wastewater treatment complexes (Figure 1).

The fertilizing properties of domestic wastewater have been known for a long time and are beyond doubt $[13,14]$. In terms of its impact on crops, sludge is comparable to horse or cow dung, however, it is contaminated with helminth eggs. In Russia, modern tested methods of sludge disinfection currently include: PUROLAT-BINGSTI preparation, heating in special apparatuses or treatment in peat-compost heaps. After anaerobic or aerobic treatment, the sludge is dewatered to a moisture content of 70 $75 \%$ and can be used as an organo-mineral fertilizer for industrial crops. Most often, a natural method of dewatering in sludge beds, special bags or geotubes is used. As for artificial methods of sludge dewatering, CPs most often include screw thickeners operating with the addition of flocculant to the sludge.

Putting a CP into operation begins with the accumulation of activated sludge, which can be produced by two methods. According to the first method, the activated sludge brought from neighboring facilities is introduced into the biological treatment unit of the plant, before putting into operation. In this case, bottom sludge of rivers, lakes or swamps can be used. During 3-5 days, the sludge is only aerated, and after that the hydraulic load is gradually increased; on the first day, about $10 \%$ of the daily amount of the wastewater is supplied, on the second day $-20 \%$, and so on. In other words, it is daily increased by $10 \%$. In about 10 days, the wastewater can be discharged to the flow path. According to the second method, activated sludge is accumulated on contaminants of the incoming wastewater. To achieve that, one $\mathrm{CP}$ line is turned off for sludge accumulation. It is preferable to provide two or four autonomously operating lines, depending on the CP performance. The line allocated for sludge accumulation is filled with the wastewater and then its aeration begins. Bubbling is necessary both to saturate the wastewater with oxygen and to keep the biomass in suspension. In about three days, zoogleal aggregates usually appear in the wastewater, which are fine particles of mineral and organic origin, populated by bacteria. On the third or fifth day, the wastewater in the amount of $10 \%$ of the hydraulic load on this CP unit, is introduced into the unit with a daily load increase by $10 \%$. In 10 days, as in the first case, the wastewater is discharged through the plant to the flow path. As a rule, CPs are put into operation in the warm period of the year, which is the most favorable for commissioning.

\section{Methods and materials}

In the course of the study, we used the results of the operation of a number of CPs located in various regions of the Russian Federation (Crimea, Western and Eastern Siberia, Yakutia (Figure 2), the Far 


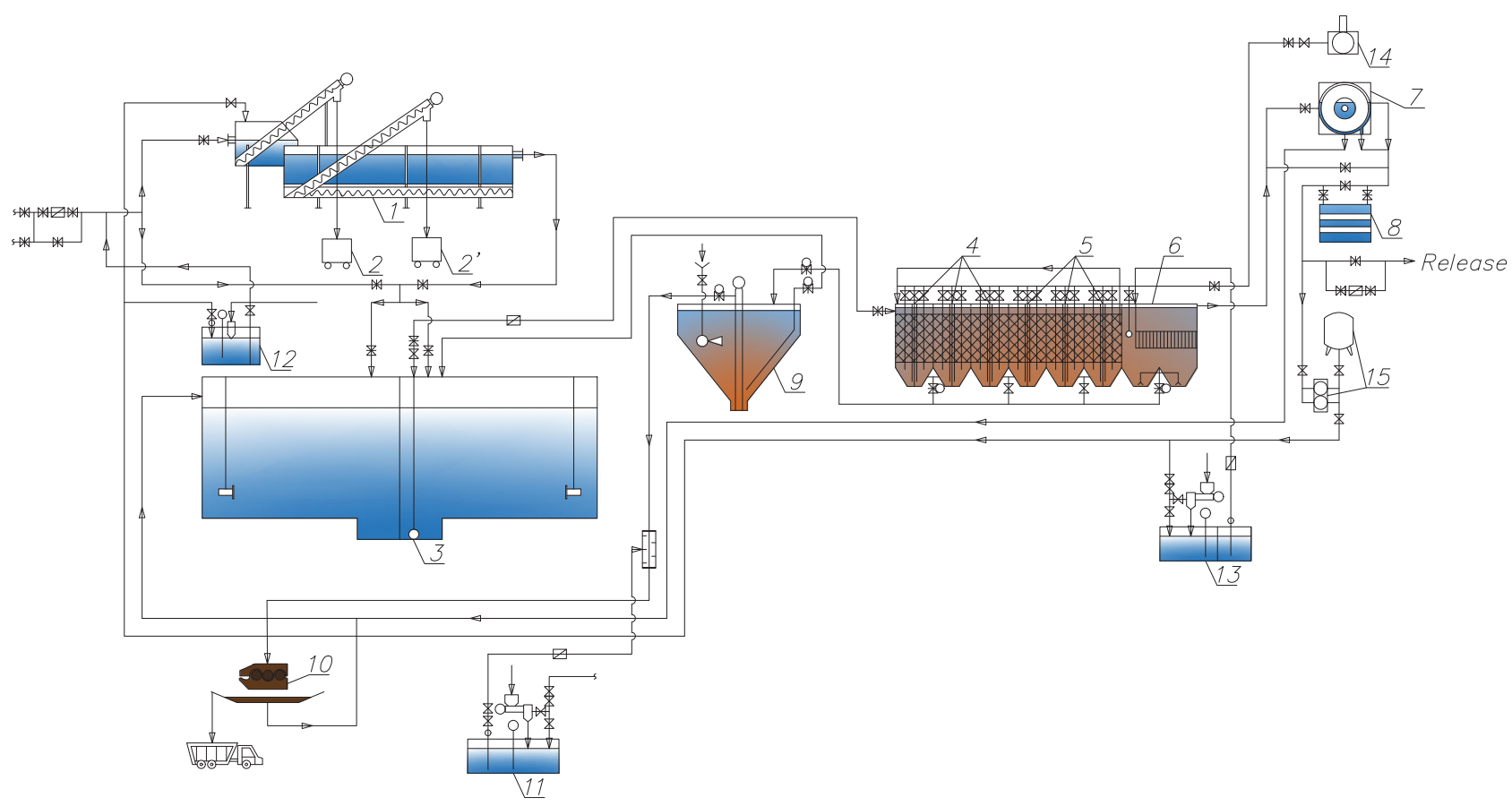

Figure 1. Process flow diagram of a compact plant (345 Mechanical Plant JSC, Balashikha, Moscow Region): 1 - screen and sand trap with screws; 2 - waste container; 2' - sand container; 3 - equalization tank; 4 - denitrification unit with biofilm carriers;

5 - bioreactor with biofilm carriers; 6 - contact filter; 7 - microfiltration unit; 8 - unit for UV disinfection of wastewater; 9 - sludge densifier; 10 - filter press; 11 - flocculant preparation and dosing unit; 12 - coagulant preparation and dosing unit; 13 - PUROLATBINGSTI ovicide preparation and dosing unit; 14 - blower; 15 - process water supply unit

East). The data of laboratory and production control of the CPs were processed by statistical analysis. We also paid special attention to the temperature influence on the CPs located in cold and hot climate zones. As for the cold climate zone, it is impossible to create favorable temperature conditions for biochemical processes, and as for the hot climate zone, it is difficult to ensure oxygen saturation of the waste liquid, which warms up in summer in open CPs to a temperature of $35-36{ }^{\circ} \mathrm{C}$. For each facility, we studied the project documentation in detail, identified all the shortcomings of the project, and determined the degree of their influence on the actual CP performance efficiency.

\section{Results and discussion}

Currently, all CPs without exception are designed with consideration for a modern technology for waste liquid treatment, ensuring nitrogen and phosphorus removal. The only problem is that the formed crystals of orthophosphoric acid circulate in the system.

Wastewater quality. The main design flaw admitted by companies offering CPs for construction is the lack of preparatory work to study the quality of the waste liquid.

Judging by the available design documentation, the proposed compact plants are intended to receive ordinary urban wastewater without taking into account its concentration in cesspools due to the likely loss of water through the slotted holes of cesspools (Tables 1, 2, 3, 4), adopted according to literary sources $[4,8,9]$.

As can be seen from Table 1, the CP can provide a reduction of the main indicators to the maximum permissible concentrations (MPC), provided that the plant receives wastewater in the amount of $300 \mathrm{~m}^{3} /$ day with $\mathrm{BOD}_{\text {ult }} 300 \mathrm{mg} / \mathrm{l}$, suspended solids concentration $260 \mathrm{mg} / \mathrm{l}$, ammonium nitrogen $26-28 \mathrm{mg} / \mathrm{l}$. In case at least one of the listed indicators of the original wastewater exceeds the limit, the declared degree of wastewater treatment cannot be ensured.

The operation of such a CP in the workers' settlement of Maslyanino (Novosibirsk Region) revealed that the indicators of the waste liquid supplied for treatment were almost 1.5 times higher than the data given in Table 2. The main problem at 


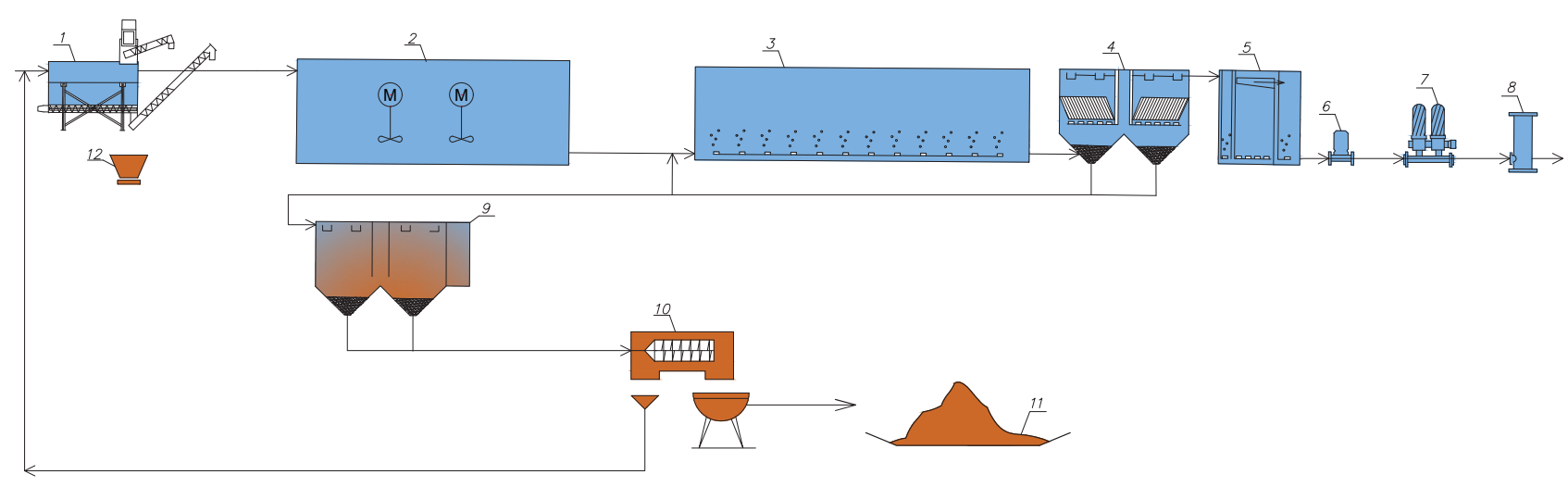

Figure 2. Process flow diagram of a compact plant in Zhatay, Republic of Sakha (Yakutia): 1 — screen combined with a sand trap compartment; 2 - equalization tank + denitrification unit; 3 - aeration tank + nitrification unit; 4 - secondary sedimentation tank with thin-layer modules; 5 - biologically treated wastewater tank; 6 - pump for water supply to the disk filter; 7 - disk filter; 8 - unit for UV disinfection of wastewater; 9 - excess activated sludge densifier; 10 - centrifuge; 11 - sludge cake storage area; 12 - waste and sand container

this facility is the excessively low temperature of the incoming wastewater (about $8{ }^{\circ} \mathrm{C}$ ), which additionally drops to $5-6{ }^{\circ} \mathrm{C}$ indoors, despite the fact that the $\mathrm{CP}$ is located in a heated building. This is facilitated by the design features and insufficient thermal insulation of the plant, which do not comply with the design area characterized by the harsh climate of Siberia with strong winds and a long cold period.

Table 1

Indicators of the original and treated wastewater at a compact plant with a capacity of $300 \mathrm{~m}^{3} / \mathrm{day}$ (Agrospetskompleks LLC)

\begin{tabular}{|c|c|c|}
\hline No. & Waste liquid indicator & $\begin{array}{c}\text { Value } \\
\text { of indicator }\end{array}$ \\
\hline \multirow[t]{4}{*}{1} & \multicolumn{2}{|c|}{ Incoming waste liquid flow rate: } \\
\hline & $\checkmark$ daily, $\mathrm{m}^{3} /$ day & 300 \\
\hline & $\checkmark$ average hourly, $\mathrm{m}^{3} / \mathrm{h}$ & 12.5 \\
\hline & $\checkmark$ maximum hourly, $\mathrm{m}^{3} / \mathrm{h}$ & 26 \\
\hline \multirow[t]{6}{*}{2} & \multicolumn{2}{|c|}{ Indicators of the original waste liquid: } \\
\hline & $\checkmark \mathrm{BOD}_{\text {ult }}, \mathrm{mg} / \mathrm{l}$ & 300 \\
\hline & $\checkmark$ suspended solids, mg/l & 260 \\
\hline & $\checkmark$ ammonium nitrogen, mg/l & $26-28$ \\
\hline & $\checkmark$ phosphate concentration $\left(\mathrm{P}_{2} \mathrm{O}_{5}\right), \mathrm{mg} / \mathrm{l}$ & 8.2 \\
\hline & $\checkmark$ active reaction $(\mathrm{pH})$ & $7.2-7.8$ \\
\hline \multirow[t]{8}{*}{3} & \multicolumn{2}{|c|}{ Indicators of the treated waste liquid: } \\
\hline & $\checkmark \mathrm{BOD}_{\text {ult }} \mathrm{mg} / \mathrm{l}$ & 3 \\
\hline & $\checkmark$ suspended solids, mg/l & 3 \\
\hline & $\checkmark$ nitrogen of ammonium salts $(\mathrm{N}), \mathrm{mg} / \mathrm{l}$ & 0.4 \\
\hline & $\checkmark \mathrm{NO}_{2}^{-}$nitrites, $\mathrm{mg} / \mathrm{l}$ & 0.08 \\
\hline & $\checkmark \mathrm{NO}_{3}^{-}$nitrates, $\mathrm{mg} / \mathrm{l}$ & 40.1 \\
\hline & $\checkmark$ phosphate concentration (P), mg/l & 0.2 \\
\hline & $\checkmark$ active reaction $(\mathrm{pH})$ & $6-8.5$ \\
\hline
\end{tabular}

As can be seen from the above data, the ratio of suspended solids $(318 \mathrm{mg} / \mathrm{l})$ and $\mathrm{BOD}_{5}(175 \mathrm{mg} / \mathrm{l})$ is somewhat unusual. Since this CP is intended for domestic wastewater treatment, then with a sewage flow rate of $2001 /$ person per day and a pollution rate of $65 \mathrm{~g} /$ person per day [8, Table 18], the concentration

Table 2

Indicators of the original and treated wastewater at a compact plant with a capacity of $1000 \mathrm{~m}^{3} /$ day (DRC Stroy Group)

\begin{tabular}{|c|c|c|}
\hline No. & Waste liquid indicator & $\begin{array}{c}\text { Value } \\
\text { of indicator }\end{array}$ \\
\hline \multirow[t]{5}{*}{1} & \multicolumn{2}{|l|}{ Incoming waste liquid flow rate: } \\
\hline & $\checkmark$ daily, $\mathrm{m}^{3} /$ day & 1000 \\
\hline & $\checkmark$ average hourly, $\mathrm{m}^{3} / \mathrm{h}$ & 42 \\
\hline & $\checkmark$ maximum hourly, $\mathrm{m}^{3} / \mathrm{h}$ & 89.4 \\
\hline & $\checkmark$ minimum hourly, $\mathrm{m}^{3} / \mathrm{h}$ & 14.28 \\
\hline \multirow[t]{7}{*}{2} & \multicolumn{2}{|c|}{ Indicators of the original waste liquid: } \\
\hline & $\checkmark \mathrm{BOD}_{\mathrm{ult}}, \mathrm{mg} / 1$ & 350 \\
\hline & $\checkmark$ suspended solids, $\mathrm{mg} / \mathrm{l}$ & 350 \\
\hline & $\checkmark$ ammonium nitrogen, $\mathrm{mg} / \mathrm{l}$ & 38 \\
\hline & $\checkmark$ total nitrogen, $\mathrm{mg} / \mathrm{l}$ & 56 \\
\hline & $\checkmark$ phosphate concentration $\left(\mathrm{P}_{2} \mathrm{O}_{5}\right), \mathrm{mg} / \mathrm{l}$ & 13 \\
\hline & $\checkmark$ temperature, ${ }^{\circ} \mathrm{C}$ & $6-25$ \\
\hline \multirow[t]{8}{*}{3} & \multicolumn{2}{|c|}{ Indicators of the treated waste liquid: } \\
\hline & $\checkmark \mathrm{BOD}_{\text {ult }}, \mathrm{mg} / \mathrm{l}$ & 3 \\
\hline & $\checkmark$ suspended solids, mg/l & 3 \\
\hline & $\checkmark$ nitrogen of ammonium salts $(\mathrm{N}), \mathrm{mg} / \mathrm{l}$ & 0.4 \\
\hline & $\checkmark \mathrm{NO}_{2}^{-}$nitrites, $\mathrm{mg} / 1$ & 0.08 \\
\hline & $\checkmark \mathrm{NO}_{3}^{-}$nitrates, mg/l & 40.1 \\
\hline & $\checkmark$ phosphate concentration (P), mg/l & 0.2 \\
\hline & $\checkmark$ active reaction $(\mathrm{pH})$ & $6-8.5$ \\
\hline
\end{tabular}


of suspended substances will be equal to $325 \mathrm{mg} / \mathrm{l}$. The calculated value $(325 \mathrm{mg} / \mathrm{l})$ is almost equal to the table value $(318 \mathrm{mg} / \mathrm{l})$. However, the $\mathrm{BOD}_{5}$ value has large deviations from the average recommended values [8, Table 18]. The calculated $\mathrm{BOD}_{5}$ value at a sewage flow rate of $200 \mathrm{1} /$ person per day is $300 \mathrm{mg} / \mathrm{l}$ or, in terms of $\mathrm{BOD}_{\text {ult }}$ it is approximately $350 \mathrm{mg} / \mathrm{l}$, while the table indicates an underestimated value of BOD $_{5}(175 \mathrm{mg} / \mathrm{l})$.

Even more confusing is the concentration of ammonium nitrogen $(\mathrm{N}) 65.2 \mathrm{mg} / \mathrm{l}$, which is higher than the values recommended [8, Table 18].

This CP was designed for the suburb of Zhatay urban village in the Republic of Sakha (Yakutia). Only a small share of waste (around $12 \mathrm{~m}^{3} /$ day) in the village will be supplied by sewage trucks. The main volume will be supplied for treatment via sewerage systems. It is scarcely probable that, in terms of the main parameters $\left(\mathrm{BOD}_{\text {ult }}\right.$, suspended solids, ammonium nitrogen), the raw waste liquid quality will appear to be close to the design values. Unfortunately, project documentation for the facility contains no data on the temperature of the incoming waste liquid and methods of its maintenance at the expected level during operation. The unit of waste liquid artificial heating was not included into the flowchart. The facility construction is already in progress, but so far only piles have been put in. For the time being, the issue of allocating phase one

Table 3 Indicators of the original and treated wastewater at a compact plant with a capacity of $2000 \mathrm{~m}^{3} /$ day (345 Mechanical Plant JSC, Balashikha, Moscow Region)

\begin{tabular}{|c|l|c|c|}
\hline \multirow{2}{*}{ No. } & \multirow{2}{*}{ Indicator } & \multicolumn{2}{c|}{$\begin{array}{c}\text { Values of the waste liquid } \\
\text { indicator }\end{array}$} \\
\cline { 3 - 4 } & & original & treated \\
\hline 1 & $\checkmark$ suspended solids, mg/l & 318 & 4 \\
\hline 2 & $\checkmark$ BOD, mg/l & 175 & $2-3$ \\
\hline \multirow{3}{*}{3} & \multicolumn{3}{|c|}{ Nitrogen group, mg/l: } \\
\cline { 2 - 4 } & $\checkmark$ ammonium (N) & 65.2 & 0.4 \\
\cline { 2 - 4 } & $\checkmark$ nitrites (N) & none & 0.02 \\
\cline { 2 - 4 } & $\checkmark$ nitrates (N) & none & 9.1 \\
\hline 4 & $\checkmark$ phosphorus, mg/l & 8.7 & 0.2 \\
\hline 5 & $\checkmark$ active reaction (pH) & 7.3 & $6.5-8.5$ \\
\hline 6 & \multicolumn{3}{|c|}{ Temperature, ${ }^{\circ} \mathrm{C}:$} \\
\cline { 2 - 4 } & $\checkmark$ in winter & 14.9 & not more than 40 \\
\cline { 2 - 4 } & $\checkmark$ in summer & $\mathrm{n} / \mathrm{d}$ & $\mathrm{n} / \mathrm{d}$ \\
\hline
\end{tabular}

of the construction project with performance of $1500 \mathrm{~m}^{3} /$ day is open.

As the analysis of few CPs, submitted for consideration with the purpose of their use in the Republic of Sakha (Yakutia), has shown, none of them meets the basic requirement: acceptance of wastewater of the respective quality (in terms of contamination and temperature) for treatment, and maintenance of the design temperature during its treatment. Therefore, they cannot provide the required degree of wastewater treatment before it is discharged into a reservoir. It is necessary, first of all, to study the quantity and quality of the waste liquid, especially the waste from cesspools, linking plants with specific localities. At first, it will be required to study the following:

$\checkmark$ list of facilities using cesspools (administrative buildings; meat, fish, vegetable processing plants; schools, kindergartens, nurseries; hospitals; saunas; laundries; stores; cinemas; individual cottages, and much more), and the duration of these facilities' operation per day (this information is required for proper selection of an equalization tank);

$\checkmark$ number of inhabitants using the certain cesspool and total flow of water discharged into this cesspool (this information is required to verify the convergence of chemical values of cesspool waste provided by analytical laboratories and obtained by calculation);

$\checkmark$ duration of daily sewage truck operation, number of trips performed, transported volume of waste delivered to the CP (this information is required for proper selection of an equalization tank, facilities of mechanical and biological wastewater treatment, tertiary treatment, and disinfection).

The obtained results of chemical analyses shall be analyzed by the following basic indicators: COD, $\mathrm{BOD}_{\text {ult }}$, suspended solids, total nitrogen $\left(\mathrm{N}_{\text {total }}\right)$ and ammonium nitrogen $\left(\mathrm{NH}_{4}^{+}\right)$expressed as $\mathrm{N}$, phosphates $\left(\mathrm{PO}_{4}{ }^{3-}\right)$ expressed as $\mathrm{P}$, hydrogen sulfide $\left(\mathrm{H}_{2} \mathrm{~S}\right)$, sulfates $\left(\mathrm{SO}_{4}^{2-}\right)$, chlorides, active reaction $(\mathrm{pH})$, waste liquid temperature for winter $\left(\mathrm{T}_{\text {win }}\right)$ and summer $\left(\mathrm{T}_{\text {sum }}\right)$ seasons, synthetic surfactants), fats, oil products, total coliform bacteria, total thermotolerant coliform bacteria, viable helminth eggs, viable cysts of enteric pathogenic protozoa.

The incoming flow of wastewater to treatment plants in small settlements is extremely nonuniform; the coefficient of daily nonuniformity can be 
Table 4

Indicators of the original and treated wastewater at a compact plant with the capacity of $3000 \mathrm{~m}^{3} /$ day (Southern Project Institute, Rostov-on-Don)

\begin{tabular}{|c|c|c|}
\hline No. & Waste liquid indicator & $\begin{array}{c}\text { Value } \\
\text { of indicator }\end{array}$ \\
\hline \multirow[t]{5}{*}{1} & \multicolumn{2}{|c|}{ Incoming wastewater flow rate: } \\
\hline & $\checkmark$ daily, $\mathrm{m}^{3} /$ day & 1000 \\
\hline & $\checkmark$ average hourly, $\mathrm{m}^{3} / \mathrm{h}$ & 125 \\
\hline & $\checkmark$ maximum hourly, $\mathrm{m}^{3} / \mathrm{h}$ & 231 \\
\hline & $\checkmark$ minimum hourly, $\mathrm{m}^{3} / \mathrm{h}$ & 65 \\
\hline \multirow[t]{7}{*}{2} & \multicolumn{2}{|c|}{ Indicators of the original waste liquid: } \\
\hline & $\checkmark \mathrm{BOD}_{\mathrm{ult}}, \mathrm{mg} / \mathrm{l}$ & $186-203$ \\
\hline & $\checkmark$ suspended solids, mg/l & 196 \\
\hline & $\checkmark$ ammonium nitrogen, $\mathrm{mg} / \mathrm{l}$ & $37-41$ \\
\hline & $\checkmark$ phosphorus (P), mg/l & $11-12$ \\
\hline & $\checkmark$ temperature, ${ }^{\circ} \mathrm{C}$ & $\mathrm{n} / \mathrm{d}$ \\
\hline & $\checkmark$ active reaction $(\mathrm{pH})$ & $7.7-7.9$ \\
\hline \multirow[t]{8}{*}{3} & \multicolumn{2}{|c|}{ Indicators of the treated waste liquid: } \\
\hline & $\checkmark \mathrm{BOD}_{\text {ult }}, \mathrm{mg} / 1$ & 3 \\
\hline & $\checkmark$ suspended solids, mg/l & 3 \\
\hline & $\checkmark$ nitrogen of ammonium salts $(\mathrm{N}), \mathrm{mg} / \mathrm{l}$ & 0.39 \\
\hline & $\checkmark \mathrm{NO}_{2}^{-}$nitrites, mg/l & 0.02 \\
\hline & $\checkmark \mathrm{NO}_{3}^{-}$nitrates, mg/l & 9 \\
\hline & $\checkmark$ phosphate concentration (P), mg/l & 0.2 \\
\hline & $\checkmark$ active reaction $(\mathrm{pH})$ & $6-8.5$ \\
\hline
\end{tabular}

higher than 3. In this case, it is mandatory to install equalization tanks. Sometimes, to reduce the volume of equalization tanks, an erroneous engineering decision is made, which is to discharge the backwash wastewater from filters or microfilters and regeneration solutions of carriers of attached microorganisms at night, not controlled by the process engineer. Such a regeneration option can only be provided for a plant operating in automatic mode. It is important to remember that biofilm carrier regeneration on one line of the tertiary treatment unit and its complete emptying will be carried out once every 5-15 days (depending on the type of biofilm carrier) with the duration of discharge for 1-2 hours.

The waste liquid temperature is a calculated indicator, on which the volume of structures and the correct selection of equipment (blowers) depend. In winter, the discharges are cooled and cooling begins in the sewer network and pumping stations. They can even be cooled in a heated building if the walls of the tank structures are not properly insulated $[1,2]$. As an example, we can consider the functioning compact plant in the settlement of Maslyanino (Novosibirsk Region) with a capacity of $1000 \mathrm{~m}^{3} /$ day (Figures 3, 4).

In the coldest months (December-January), the temperature of wastewater in the biological treatment facilities of this plant drops from $7-8$ to $5-6^{\circ} \mathrm{C}$, the biochemical oxidation processes practically stop, and wastewater treatment occurs only due to sorption of organic substances on the surface of activated sludge. The processes of activated sludge separation in secondary sedimentation tanks deteriorate, and, as a result, suspended solids and BOD in the treated wastewater increase from 10 and 15 to 60 and $90 \mathrm{mg} / \mathrm{l}$, respectively. The plant is located indoors, the most effective insulation is used for the walls, the second floor of the building is heated, and the processes of aerobic oxidation of organic substances proceed with the release of heat from exothermic reactions. Nevertheless, during the cold season, the waste liquid cools down significantly. In a detailed examination of the facility's technical condition, we found out the reasons for the decrease in temperature. During the construction of the facility, thermal insulation of the building walls was applied incorrectly (including the walls of the following structures: equalization tank, areas with aeration tanks, secondary sedimentation tanks, and bioreactors for tertiary treatment). In addition, due to the lack of a heating system, the discharges are cooled at the level of the first floor, where, in the cold period, temperature drops to $0-1{ }^{\circ} \mathrm{C}$ and is maintained at this level due to the heat transfer from the open surfaces of the walls of the secondary sedimentation tanks and bioreactors. Due to the critical situation at the facility, the issue of waste liquid artificial heating is currently open.

The bioreactor of the first stage of tertiary treatment with carriers of attached microorganisms is one of the innovative engineering solutions. A serious disadvantage of classical tertiary treatment using sand filters is the impossibility to receive wastewater for tertiary treatment at a concentration of suspended solids washed out from the secondary sedimentation tanks of more than $20 \mathrm{mg} / \mathrm{l}$. In comparison with microfilters, which are also used at the first stage of tertiary treatment, bioreactors with carriers are easier to operate and cheaper to build, can provide a better treatment in terms of $\mathrm{BOD}_{\text {ult }}$ and ammonium nitrogen, and also do not require large water consumption for regeneration. The type of 
carrier is selected depending on many factors: first of all, on the preferences of designers, since the carrier's cost and specifications play an important role. Today, brushes are the most well-known and tested carriers at many facilities. The introduction of bioreactors with brushes in treatment facilities is an advantage and a disadvantage at the same time. The indisputable advantages of these structures include the ability to provide a high degree of wastewater treatment during the massive washout of activated sludge from the secondary sedimentation tanks, caused by its "swelling" in the aeration tanks. All other conditions being equal, the operating costs of bioreactors with biofilm carriers are lower than those of microfilters. However, this is also a disadvantage, since the constant unsatisfactory biofilm carrier regeneration can cause repeated contamination of the treated wastewater. Today, the issue of highquality biofilm carrier regeneration at this facility remains open.

Regeneration of brushes. Almost all CPs are provided with carriers of attached microorganisms; however, the explanatory notes do not clearly specify the method of regeneration for brushes and other types of carriers of attached microorganisms. Carriers are introduced into the areas of denitrification, full aerobic oxidation of organic substances, and nitrification; sometimes they are used even in aerobic stabilizers, however, it is not clear why. In the last $10-15$ years, the mass use of carriers of attached microorganisms for biological treatment or tertiary treatment facilities has created huge problems for WWTP operating personnel, related to the quality of the treated wastewater. The constant unsatisfactory regeneration of brushes eventually leads to repeated contamination of the treated wastewater. This can be proved by the operation of wastewater treatment complexes in the workers' settlement of Maslyanino (Novosibirsk Region), the city of Mirny (Republic of Sakha (Yakutia)), and local sewage treatment facilities of the advanced grain processing plant in the town of Ishim (Tyumen Region). The accumulated biofilm, which was not timely removed, decayed and deteriorated the indicators of the treated waste liquid. The plant was forced to get rid of the biofilm carriers. We believe that carriers are especially disadvantageous in nitrification areas, where the stage of biological treatment is completed.

\section{Thin-layer modules of secondary sedimentation} tanks. In the USSR, the use of thin-layer modules was started in the 1970s but they still are classified as innovative engineering solutions (although by a long stretch of the imagination). It is possible that, due to the insufficient amount of accumulated information, the issue of module regeneration still remains open. Currently, two non-standard regeneration methods are known: with water and with air. In the first case, a strong jet washing away the sediment from the module shelves is used; in the second case, regeneration is performed with air by their sharp shaking. In this regard, two questions arise. First, where is the partially decayed sludge mixture

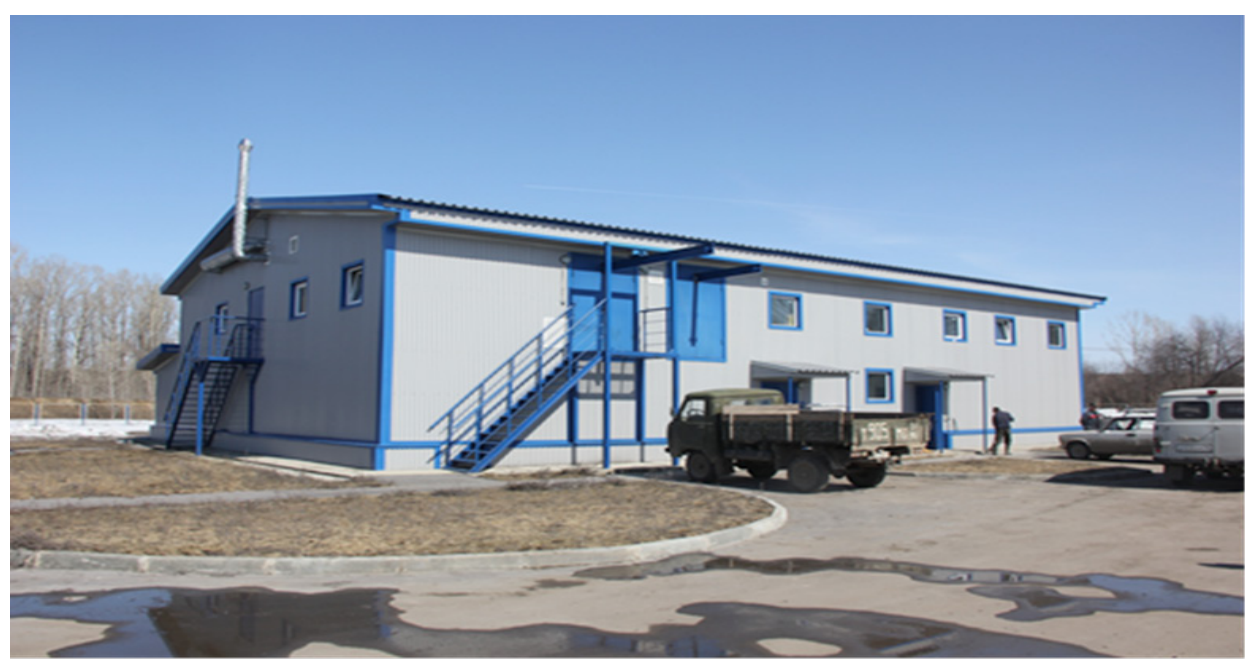

Figure 3. Building of the sewage treatment plant in the workers' settlement of Maslyanino, Novosibirsk Region 


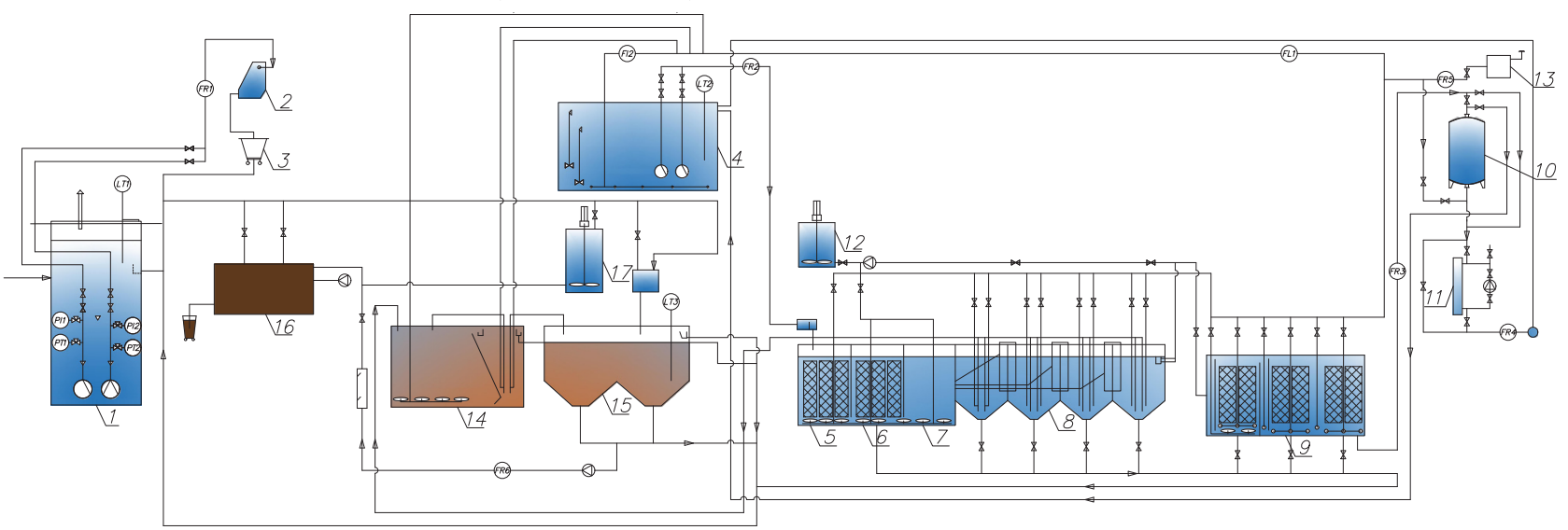

Figure 4. Process flow diagram of a compact plant in the workers' settlement of Maslyanino, Novosibirsk Region: 1 - main pumping station; 2 - screen; 3 - waste receiver; 4 - equalization tank; 5 - denitrification area; 6 - area of aerobic oxidation of organic substances; 7 - nitrification area; 8 - secondary sedimentation tank; 9 - bioreactor of the first stage of tertiary treatment; 10 - sand filter for the second stage of tertiary treatment; 11 - unit for UV disinfection of wastewater; 12 - reagent preparation and dosing unit; 13 - blower; 14 - aerobic stabilizer; 15 - stabilized sludge densifier; 16 - dewatering press; 17 - flocculant preparation unit

washed away from the shelves, and how its discharge will affect the operation of the biological treatment facilities if the return is made to the denitrification unit? Second, can the thin-layer module bracing withstand repeated exposure to air for a long period of time? There were cases when modules were torn off with such an air regeneration system at the stage of start-up and commissioning (Ishim town, Tyumen Region).

Phosphorus removal. At all $\mathrm{CPs}$, the chemical method of phosphorus removal is applied. As a reagent, Aqua-Aurat or RAX-XL-100 is most often used. The reagents are introduced at the stage of biological or tertiary treatment carried out biologically in bioreactors. Such options make it possible to reduce phosphorus to MPC, but disrupt the effective and stable operation of the corresponding units. A decrease in phosphorus levels at these stages to $0.2 \mathrm{mg} / 1$ destabilizes the operation of the biological or tertiary treatment unit due to an acute phosphorus deficiency. With such a deficiency at the stage of biological treatment, "swelling" of activated sludge occurs, caused by the intensive development of filamentous bacteria, and its sedimentation properties deteriorate. During this period, the washout of activated sludge particles can reach $100 \mathrm{mg} / 1$. The introduction of Aqua-Aurat or RAX-XL-100 reagents at the stage of biological or tertiary treatment will cause a number of issues associated not only with the "swelling" of activated sludge (settlement of Maslyanino, Novosibirsk Region).

Disk filters (sometimes called microfilters). In many cases, CPs include disk microfilters. However, there is very little information on this equipment since the material of the filter cloth and its characteristics as well as the water pressure and flow rate required for high-quality washing of the filter element are not specified. The technical documentation does not disclose the specifics of equipment operation. In comparison with sand filters, disk microfilters are cheaper and have a simpler design, but they are inferior to them in terms of wastewater treatment efficiency and operation stability. Disk microfilters cannot physically reduce the concentration of suspended substances to $0-1 \mathrm{mg} / 1$, while sand filters with a filter media grain diameter of $0.6-1.2 \mathrm{~mm}$ can ensure such a result.

Clean water tank. Almost all CPs are provided with tertiary wastewater treatment carried out in one, two, and sometimes even three stages. Meanwhile, many facilities do not even have clean and dirty water tanks. As a result, the filters are washed with water that has passed the first stage of tertiary treatment (bioreactors with biofilm carriers), which is not always of good quality. Due to the lack of clean water tanks, no deeply purified water is used for process needs (e.g., preparation of reagent and flocculant solutions, regeneration of filter press belts, washing of equipment and structures during 
their preventive cleaning). Instead, tap water is used, which in some cases is even imported by road.

Aerobic densifier. Some CPs include an aerobic densifier, providing no information about its function. Judging from the duration of excess activated sludge staying in the densifier ( 2.5 days), it plays a role of an aerobic stabilizer. If this is true, then it shall be characterized by periodic operation, i.e., after its loading with excess sludge, the air lift comes into the operation, partial mineralization of excess sludge takes place, in two days the air lift turns off temporarily (for 5 hours max), and the mixed liquor is densified; afterwards, the sediment is pumped out, and then the remaining sludge water is removed. This procedure poses two issues. First, is it possible to ensure daily uninterrupted pumping of excess activated sludge from any biological treatment line into any aerobic densifier if there is no unified sludge removal system? Second, can the operation mode of the aerobic sludge densifier be called sediment aerobic mineralization? With such cyclic operation of the aerobic densifier, it is impossible to obtain the mature aerobically stabilized sediment, i.e., to ensure stable operation of this sediment treatment unit.

Sediment treatment. Most often, CP sediment treatment is carried out according to a truncated procedure, which only provides for sediment dewatering in dewatering presses of various modifications. Sometimes, in the case of one type of sediment (excess activated sludge), aerobic densifiers designed for short (2-3 days) sediment staying are introduced. Such structures cannot ensure normal aerobic stabilization of sediment; moreover, they cannot even prevent the appearance of an unpleasant smell. We believe that, at small facilities, aerobic stabilization is considered the safest and most affordable and effective, although the most energyconsuming method of sediment treatment. With aerobic stabilization, the dry substance is reduced by about $30 \%$ in mass, the sediment has no smell, and having a good water loss ability, reduces the amount of flocculant during mechanical dewatering and the size of sludge beds during natural sediment dewatering.

Sediment dewatering. The weak point of all the considered CPs is not only sediment treatment but also its dewatering, which is carried out in dewatering presses using flocculant. This equipment cannot ensure sediment dewatering to a moisture of
$75 \%$, i.e., its loose condition. It is possible to reduce moisture only to $80 \%$, thus, when being transported, such sediment usually liquefies and part of it is lost on the way from the CP to the storage site.

Sediment disinfection. At most CPs, for the dehelminthization of both raw sediment and excess activated sludge, PUROLAT-BINGSTI ovicide is used. It is introduced into the equalization tank or upstream of the sediment treatment unit. Waste and sand are disinfected with chlorinated lime.

CP laboratory. In the future, the main issue of all CPs will be the lack of laboratories for monitoring at least those analyses that are necessary to determine the $\mathrm{CP}$ performance efficiency by the main indicators: suspended solids and BOD. The laboratory is the "eyes" of sewage treatment plants, and without it, it is impossible to ramp up a CP to normal mode during start-up and maintain this mode during continuous operation. Currently, CPs are not equipped with chemical laboratories; analyses are performed by analytical laboratories, most often by the Center of Laboratory Analysis and Technical Metrology.

Instrumentation. All CPs are characterized by the low level of control over wastewater and sediment treatment.

Smell. One of the main issues at the CPs located indoors is strong smell in all production premises. It comes from the screens, equalization tank, aerobic stabilizer, and stabilized sediment densifier through the openings, and from the open surface of the nitrification and denitrification units as well as bioreactors. The smell intensifies when the process of the biochemical oxidation of the organic matter is disturbed, which is due to a decrease in the waste liquid or stabilized sediment temperature, insufficient aeration of the waste liquid, and many other factors.

Taking into account the abovementioned facts, a process flow diagram for domestic wastewater treatment is given below, which can be used in CP design (Figure 6).

According to it, wastewater is fed from the main pumping station to the screens with the openings of $2-4 \mathrm{~mm}$ or, which is better, to the sieve with the openings of 1-2 $\mathrm{mm}$, where it is cleaned from large inclusions; mineral particles are retained by the sand trap. After dewatering, waste and mineral sediment are mixed with chlorinated lime and taken to a solid waste landfill. If a $\mathrm{CP}$ receives drains from cesspools, 


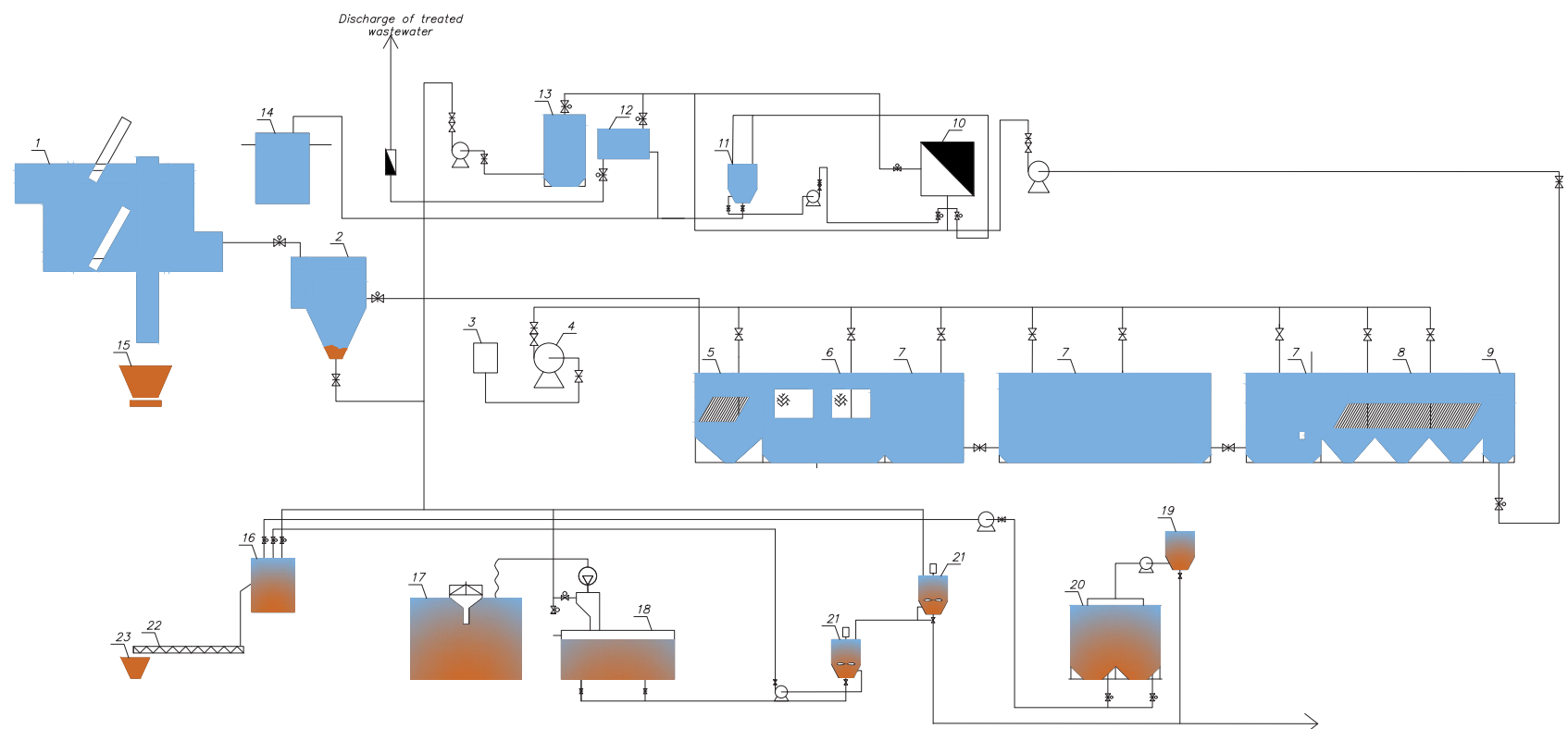

Figure 5. Process flow diagram of local sewage treatment facilities of the Plemzavod-Yubileiny agricultural holding (Ishim town, Tyumen Region): 1 - screen; 2 - sand trap; 3 - air filter; 4 - blowers; 5 - primary sedimentation tank; 6 - denitrification unit; 7 - aeration tank; 8 - secondary sedimentation tank; 9 - clean water tank; 10 - membrane unit; 11 - reagent unit for washing solution; 12 - disinfection unit; 13 - wash water tank; 14 - pit; 15 - waste hopper; 16 - dewatering press; 17 - container for dry reagent; 18 - reagent unit for coagulant; 19 - reagent unit for sludge disinfection; 20 - sludge densifier; 21 - reagent unit for sludge treatment; 22 - screw conveyor; 23 - hopper for dry sludge

then screens and sand traps are provided at the drain station to retain large inclusions and sand. The drains are diluted with industrial water at a ratio of 1:2. The treated waste liquid from the CP can serve as process water. The drains from the drain station are discharged to the main pumping station, from where they are pumped out for treatment.

The equalization tank volume shall be calculated with regard to the schedule of waste liquid inflow, and if it is absent, the volume shall be selected based on the experience of operation bearing in mind 10-15 hours of waste staying in this unit. In order to maintain the temperature, required for biological treatment, during the unfavorable winter period, the waste liquid shall be heated, and this heating shall be performed outside the building, which will make it possible to easily clean heat exchangers in the case of scale accumulation.

The equalization tank can be used as a denitrification unit, which will make it possible to avoid smell in the $\mathrm{CP}$ building and create comfortable conditions for the staff since activated sludge is an efficient sorbent of hydrogen sulfide, ammonia, indole, and mercaptans.
For areas with severe climatic conditions, at the equalization stage, waste liquid heating is provided using heat exchangers located either in the equalization tanks or outside them. These heat exchangers can have different designs: metal plates laid along the bottom of the equalization tank; a "pipe in a pipe" system placed on the pressure line of the pumps pumping the waste liquid out of the tanks. To maintain activated sludge in suspension, mixing in the equalization tank (denitrification unit) shall be carried out using agitators or air. In this case, the blower shall operate in the pulse-pause mode, i.e., it shall be switched on every 10 minutes with operation duration of approximately $1-1.5$ minutes. Any mixing method shall ensure the concentration of dissolved oxygen in this area at the level of 0.1$0.5 \mathrm{mg} / 1$. The practice of operation has shown that the denitrification process proceeds successfully even in the complete absence of dissolved oxygen. The nitrified activated sludge is fed into the equalization tank both through the external (from the secondary sedimentation tanks) and internal (from the end of the nitrification area) circulation circuits. It should be noted that the unpleasant smell coming from the equalization tank can also be eliminated 
by introducing sodium hydroxide $(\mathrm{NaOH})$ into it in order to increase the $\mathrm{pH}$ level to 8.3-8.5. At such $\mathrm{pH}$ values, all hydrogen sulfide $\left(\mathrm{H}_{2} \mathrm{~S}\right)$ is in a soluble state.

After the reduction of nitrites and nitrates to elemental nitrogen, which partially consumes organic substances, the sludge mixture from the equalization tank (denitrification unit) is uniformly fed to the aerobic zone, where the remaining part of organic pollutants is fully oxidized. This zone is designed to reduce $\mathrm{BOD}_{\text {ult }}$ to $15 \mathrm{mg} / \mathrm{l}$. Here, biofilm carriers (brushes, nylon mesh, or other types of carriers of attached microorganisms) can be placed. It is not recommended to place those in nitrification areas, since during operation, with poor-quality regeneration of carriers, there is a great risk of secondary contamination of the biologically treated waste liquid, accompanied by an increase in BOD, suspended solids, ammonium nitrogen and phosphates. This negative impact can be avoided if high-quality regeneration (e.g., with air) is ensured. The intensity of aeration in this case shall be 5-10 times higher than that used to saturate the waste liquid with oxygen in the aeration tank; the optimal intensity is selected experimentally in production conditions. In the areas of biofilm carrier placement, it is necessary to provide an independent system of medium-bubble aeration for carrier regeneration. Air is supplied to this aeration system from blowers (one operating and one emergency) intended exclusively for carrier regeneration.

Then the sludge mixture passes through the nitrification unit and flows by gravity into the secondary sedimentation tanks, which can have thin-layer modules. It is important to ensure highquality regeneration of the modules and uniform pumping of the partially decayed sludge out of the module shelves into the denitrification unit. As a rule, activated sludge is pumped out of the pits of the secondary sedimentation tanks by air lifts. This method is fairly good provided that each air lift is equipped with metering devices for the supplied air and the pumped sludge mixture. Sludge can also be pumped out by submersible pumps in the case of a small number of pits.

After separation of the sludge mixture in the secondary sedimentation tanks, the nitrified sludge is returned to the denitrification unit, and the biologically treated liquid is sent for tertiary treatment. Both the classical version of tertiary treatment, including microfilters or drum screens in combination with sand filters, and more affordable

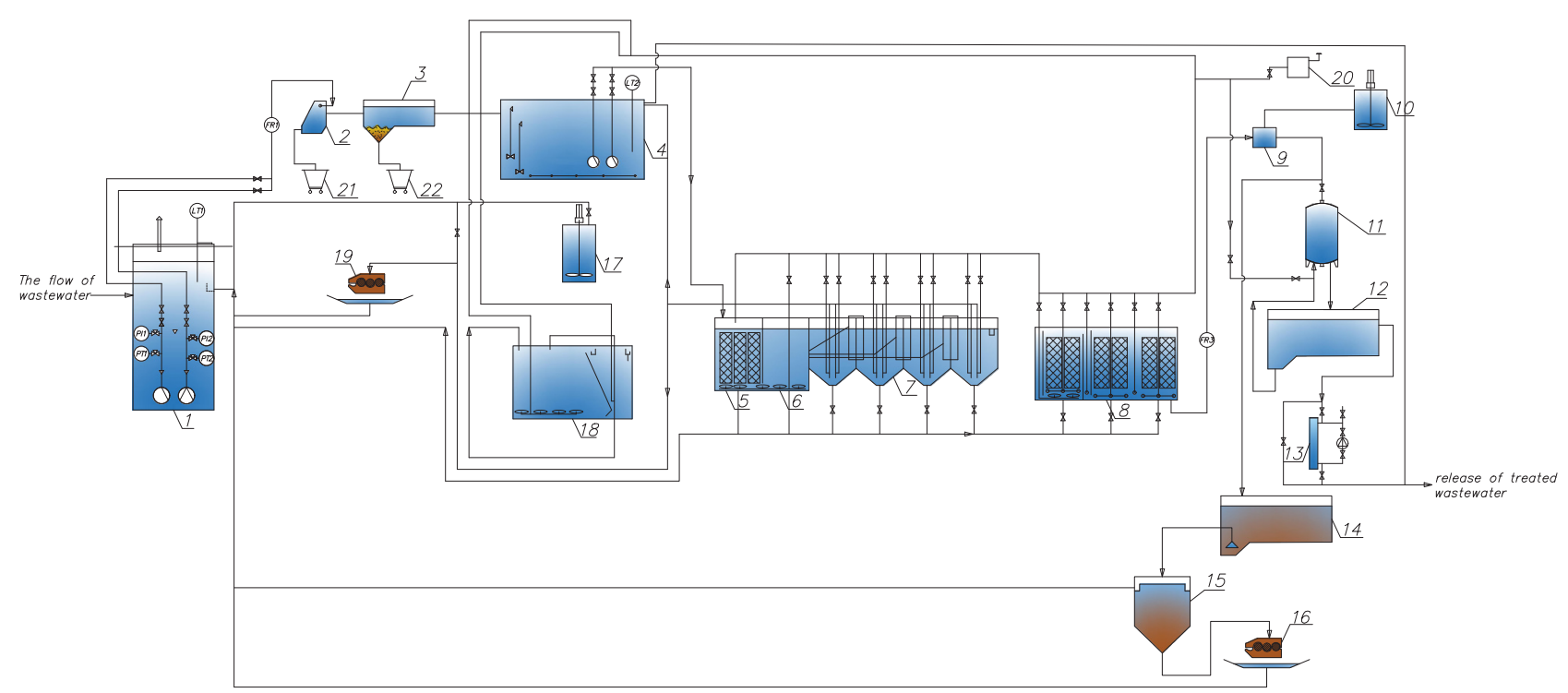

Figure 6. Technology of wastewater and sediment treatment: $1-$ main pumping station; 2 - screen with the openings of 2-4 mm (or sieve); 3 - sand trap; 4 - equalization tank + denitrification area; 5 - area of full oxidation of organic substances under aerobic conditions; 6 - nitrification unit; 7 - secondary sedimentation tank; 8 - bioreactor of the first stage of tertiary treatment; 9 - reaction chamber; 10 - coagulant preparation unit; 11 - sand filter of the second stage of tertiary treatment; 12 - clean water tank; 13 - unit for UV disinfection of wastewater; 14 - dirty water tank; 15 - crystal separator; 16 - filter press for dewatering of the crystalline sediment; 17 - flocculant preparation unit; 18 - aerobic stabilizer; 19 - unit for dewatering of the organic sediment; 20 - blower; 21 - waste container; 22 - dry sand container 
and quite effective technologies can be used. Such technologies involve bioreactors with biofilm carriers combined with sand filters. The carriers retain activated sludge washed out from the secondary sedimentation tank during its "swelling" at the stage of biological treatment. As already noted, even in this case, it is necessary to provide separate blowers and a separate air distribution system for carrier regeneration. It is recommended to discharge dirty water formed during carrier regeneration into the tank for dirty water from the filters and return it uniformly to the $\mathrm{CP}$ beginning for repeated tertiary treatment.

Phosphorus shall be removed at the last stage of tertiary treatment (filters), which eliminates the negative impact of low phosphorus concentrations on the processes of wastewater treatment and tertiary treatment. The free ion phosphates extracted from the waste liquid in the form of orthophosphoric acid crystals shall be removed from the washing water of the filters, which will require additional introduction of a crystal separator and a unit for dewatering of the crystalline sediment. It is advisable to return the sludge water from the crystal separator and the unit for dewatering of the crystalline sediment before tertiary treatment.

It is recommended to provide treatment of the organic sediment in aerobic conditions, both with and without subsequent densification. For dewatering, it is necessary to use modern high-efficiency filter presses of small capacity, which reduce the moisture of the dewatered sediment to about $75 \%$; and for disinfection, the tested PUROLAT-BINGSTI ovicide can be used. The organic and organo-mineral sediment shall be dewatered separately.

Stable trouble-free operation of the wastewater treatment complex is possible if at the design stage, depending on the CP performance, 3-4 independently operating lines are provided for waste liquid treatment. In order to avoid emergency shutdowns, the number of tanks for clean and dirty water, crystal separators, aerobic stabilizers, filter presses, units for dewatering of the organo-mineral sediment, and blowers shall be at least two each.

All CPs without exception shall be equipped with field laboratories to determine the main indicators of the waste liquid and sediment for the purpose of elementary process control. When designing the $\mathrm{CP}$ automation system, it is necessary to provide for constant monitoring of temperature, $\mathrm{pH}$, dissolved oxygen, and ammonium nitrogen in the biological treatment unit; and in the tertiary treatment unit, it is necessary to provide for monitoring of phosphorus.

\section{Conclusion}

The in-depth analysis of the designs of compact plants developed and currently operating as well as the technologies of wastewater treatment allowed us to identify the main shortcomings hindering the achievement of the required degree of wastewater treatment, develop and recommend for implementation the optimal process flow of wastewater and sludge treatment.

\section{Литература}

1. Ambrosova, G. and Kruglikova, A. (2016). Affect of climatic conditions on the efficiency of work of open wastewater treatment plant. In: $8^{\text {th }}$ International Conference on Contemporary Problems of Architecture and Construction, October 26-28, 2016. Yerevan: National University of Architecture and Construction of Armenia, pp. 3-6.

2. Амбросова, Г. Т., Кругликова, А. В., Мансуров, Р. Ш., Рафальская, Т. А. и Тимофеев, С. Л. (2019). Влияние природно-климатических факторов на эффективность работы открытых очистных сооружений канализации. Водоснабжение и санитарная техника, № 4, сс. 48-59.

3. Амбросова, Г. Т., Семенова, А. П. и Колодезникова, А. П. (2018). Компактные установки для очистки бытовых стоков. Строительство и техногенная безопасность, № 12 (64), cc. $109-115$.

4. Возная, Н. Ф. (1979). Химия воды и микробиология. 2-е издание. М.: Высшая школа, 340 с.

5. Залетова, Н. А. (1999). Очистка городских сточных вод от биогенных веществ (соединений азота и фосфора). Диссертация на соискание ученой степени доктора технических наук. М.: Научно-исследовательский институт коммунального водоснабжения и очистки воды.

6. Колобанов, С. К., Ершов, А. В. и Кигель, М. Е. (1977). Проектирование очистных сооружений канализации. К.: Будівельник, 224 с.

7. Лукиных, Н. А., Липман, Б. Л. и Криштул, В. П. (1978). Методы доочистки сточных вод. 2-е издание. М.: Стройиздат, $156 \mathrm{c}$.

8. Министерство строительства и жилищнокоммунального хозяйства Российской Федерации (2019). Свод правил СП 32.13330.2018. Канализация. Наружные сети и сооружения. СНиП 2.04.03-85. М.: Стандартинформ, $70 \mathrm{c}$.

9. Мирный, А. Н., Скворцов, Л. С., Пупырев, Е. И. и Корецкий, В.Е.(2007). Коммунальная экология. М.: Прима-Пресс-М, 806 с.

10. Рандольф, Р. (1987). Что делать со сточными водами. 2-е издание. М.: Стройиздат, 120 c.

11. Самохин, В. Н. (ред.) (1981). Канализация населенных мест и промышленных предприятий. 2-е издание. М.: Стройиздат, 639 с.

12. Степанов, С. В. (2020). Технологический расчет аэротенков и мембранных биореакторов. М.: АСВ, 224 с.

13. Яковлев, С. В. и Воронов, Ю. В. (2002). Водоотведение и очистка сточных вод. 2-е издание. М.: ACB, $703 \mathrm{c}$. 
14. Яковлев, С. В., Карелин, Я. А., Жуков, А. И. и Колобанов, С. К. (1975). Канализация. 5-е издание. М.: Стройиздат, $632 \mathrm{c.}$

15. Яковлев, С. В. и Карюхина, Т. А. (1980). Биохимические процессы в очистке сточных вод. М.: Стройиздат, 200 c.

\section{References}

1. Ambrosova, G. and Kruglikova, A. (2016). Affect of climatic conditions on the efficiency of work of open wastewater treatment plant. In: $8^{\text {th }}$ International Conference on Contemporary Problems of Architecture and Construction, October 26-28, 2016. Yerevan: National University of Architecture and Construction of Armenia, pp. 3-6.

2. Ambrosova, G. T., Kruglikova, A. V., Mansurov, R. Sh., Rafal'skaia, T. A. and Timofeev, S. L. (2019). Impact of natural and climatic factors on the efficiency of open wastewater treatment facilities operation. Water Supply and Sanitary Technique, No. 4, pp. 48-59.

3. Ambrosova, G. T., Semenova, A. P. and Kolodeznikova, A. P. (2018). Compact plants for cleaning household drains. Construction and Industrial Safety, No. 12 (64), pp. 109-115.

4. Voznaya, N. F. (1979). Water chemistry and microbiology. $2^{\text {nd }}$ edition. Moscow: Vysshaya Shkola, 340 p.

5. Zaletova, N. A. (1999). Treatment of urban wastewater to remove biogenic substances (nitrogen and phosphorus compounds). DSc Thesis in Engineering. Moscow: Research Institute of Municipal Water Supply and Water Treatment.

6. Kolobanov, S. K., Yershov, A. V. and Kigel, M. Ye. (1977). Design of sewage treatment plants. Kiev: Budivelnik, $224 \mathrm{p}$.

7. Lukinykh, N. A., Lipman, B. L. and Krishtul, V. P. (1978). Methods of wastewater tertiary treatment. $2^{\text {nd }}$ edition. Moscow: Stroyizdat, $156 \mathrm{p}$.

8. Ministry of Construction, Housing and Utilities of the Russian Federation (2019). Regulations SP 32.13330.2018. Sewerage. Pipelines and wastewater treatment plants. Construction Rules and Regulations SNiP 2.04.03-85. Moscow: Standartinform, $70 \mathrm{p}$

9. Mirny, A. N., Skvortsov, L. S., Pupyrev, Ye. I., and Koretsky, V. Ye. (2007). Municipal ecology. Moscow: PrimaPress-M, $806 \mathrm{p}$.

10. Randolf, R. (1987). What to do with wastewater. $2^{\text {nd }}$ edition. Moscow: Stroyizdat, $120 \mathrm{p}$.

11. Samokhin, V. N. (ed.) (1981). Sewerage of settlements and industrial enterprises. $2^{\text {nd }}$ edition. Moscow: Stroyizdat, $639 \mathrm{p}$.

12. Stepanov, S. V. (2020). Design calculation of aeration tanks and membrane bioreactors. Moscow: ASV, $224 \mathrm{p}$.

13. Yakovlev, S. V. and Voronov, Yu. V. (2002). Wastewater disposal and treatment. $2^{\text {nd }}$ edition. Moscow: ASV, 703 p.
14. Yakovlev, S. V., Karelin, Ya. A., Zhukov, A. I. and Kolobanov, S. K. (1975). Sewerage. $5^{\text {th }}$ edition. Moscow: Stroyizdat, $632 \mathrm{p}$.

15. Yakovlev, S. V. and Karyukhina, T. A (1980). Biochemical processes in wastewater treatment. Moscow: Stroyizdat, $200 \mathrm{p}$.

Authors

Galina Tarasovna Ambrosova, $\mathrm{PhD}$ in Engineering, Professor

Novosibirsk State University of Architecture and Civil Engineering (Sibstrin), Novosibirsk, Russia

E-mail: galina-ambrosova@yandex.ru

\section{Anastasiia Valerevna Kruglikova}

Novosibirsk State University of Architecture and Civil Engineering (Sibstrin), Novosibirsk, Russia

E-mail: nastikrug@mail.ru

\section{Aiyyna Petrovna Kolodeznikova}

Novosibirsk State University of Architecture and Civil Engineering (Sibstrin), Novosibirsk, Russia

E-mail: by_karlson@mail.ru

Anastasiia Petrovna Semenova

Novosibirsk State University of Architecture and Civil Engineering (Sibstrin), Novosibirsk, Russia

E-mail: anastasiya.semenova.1995@list.ru

\section{Авторы}

Амбросова Галина Тарасовна, канд. техн. наук, профессор

Новосибирский государственный архитектурностроительный университет (Сибстрин), Новосибирск, Россия

E-mail: galina-ambrosova@yandex.ru

Кругликова Анастасия Валерьевна

Новосибирский государственный архитектурностроительный университет (Сибстрин), Новосибирск, Россия

E-mail: nastikrug@mail.ru

\section{Колодезникова Айыына Петровна}

Новосибирский государственный архитектурностроительный университет (Сибстрин), Новосибирск, Россия

E-mail: by_karlson@mail.ru

\section{Семенова Анастасия Петровна}

Новосибирский государственный архитектурностроительный университет (Сибстрин), Новосибирск, Россия

E-mail: anastasiya.semenova.1995@list.ru 